\title{
Assessment of weight gain and biological parameters of Rhipicephalus sanguineus females fed artificially via capillary tubes
}

\author{
Avaliação do ganho de peso e dos parâmetros biológicos de fêmeas Rhipicephalus sanguineus \\ alimentadas artificialmente por meio de tubos capilares
}

\author{
Nathalie Costa da Cunha' Charles Passos Rangel ${ }^{I}$ Eliane Mattos Piranda ${ }^{I I}$ Jania de Rezende \\ Rafaella Câmara Teixeira ${ }^{\mathrm{I}}$ Adivaldo Henrique da FonsecaII
}

\begin{abstract}
This study assesses the weight gain of partially engorged Rhipicephalus sanguineus females that were artificially fed via capillary tubes and the influence of capillary tube feeding on the biological parameters of the non-parasitic stage of the species. The ticks were sorted into four groups, each containing ten females of a homogeneous weight. The groups were each treated for different feeding times, 2, 6, 12 and 24 hours. The weight gain of the artificially fed females was measured, and the biological parameters of the non-parasitic stage of the tick were observed for each treatment group. The statistical nonparametrical Dunn and Kruskal-Wallis tests were used to compare the results. The mean weights $(\mathrm{mg})$ were $0.2 \pm 2.4$; $4.3 \pm 5.8 ; 7.4 \pm 5.8$ and $12.0 \pm 11.2$ for the 2, 6, 12 and 24 hours feeding groups, respectively. The weight of the fed groups increased as the capillary feeding time increased, and this relationship was highly significant $(P<0.05)$ between the groups fed for 2 and 24 hours. No statistically significant differences $(P>0.05)$ were observed in the parameters of the non-parasitic stage for the artificially fed groups. It can be concluded that artificial feeding via capillary tubes provides an efficient and easy method for the artificial intake of blood by $\boldsymbol{R}$. sanguineus. Furthermore, it was noted that the ticks fed in vitro were able to establish a new generation. The experimental method shows great promise in studies that aim to investigate biological disease agents.
\end{abstract}

Key words: feeding in vitro, capillary tube, ixodidae.

\section{RESUMO}

O objetivo deste trabalho foi avaliar o ganho de peso de fêmeas Rhipicephalus sanguineus parcialmente ingurgitadas alimentadas artificialmente por meio de tubos capilares e verificar a sua influência nos parâmetros biológicos

\begin{abstract}
da fase não parasitária. Os carrapatos foram separados em quatro grupos de peso homogêneo compostos por 10 fêmeas cada. Os grupos foram submetidos a diferentes tempos de alimentação: 2, 6, 12 e 24 horas. Para comparação dos resultados, foram utilizados os testes estatísticos não paramétricos Dunn e Kruskal-Wallis. Os pesos médios (mg)

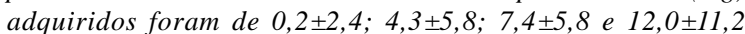
nos grupos de 2, 6, 12 e 24 horas, respectivamente. O peso dos grupos alimentados foi maior à medida que o tempo de exposição ao tubo capilar aumentou, observando-se diferença significativa $(P<0,05)$ entre os grupos alimentados por 2 e 24 horas. Não houve diferenças estatísticas significativas $(P>0,05)$ nos parâmetros relativos à fase não parasitária entre os grupos submetidos à alimentação artificial. Concluiu-se que a alimentação artificial por meio de tubos capilares é um método de fácil execução e eficiente para ingestão de sangue por carrapatos $\boldsymbol{R}$. sanguineus. Além disso, verificou-se que os carrapatos alimentados in vitro foram capazes de estabelecer uma nova geração. Esse método tem potencial para o desenvolvimento de estudos que visem a transmissão de bioagentes.
\end{abstract}

Palavras-chave: alimentação in vitro, tubo capilar, ixodídeos.

\section{INTRODUCTION}

The Rhipicephalus genus is comprised of approximately 70 tick species, almost all of which are native to the tropical regions of the African continent. This importance is imputed to the direct damage caused by the ticks and to their potential to transmit pathogens to the dogs. Previous research has investigated the

\footnotetext{
ICurso de Pós-graduação em Ciências Veterinárias, Departamento de Parasitologia Animal, Universidade Federal Rural do Rio de Janeiro (UFRRJ), Seropédica, RJ, Brasil.

IIEscola Superior Batista do Amazonas, Manaus, AM, Brasil.

IIIDepartamento de Epidemiologia e Saúde Pública, UFRRJ, 23890-000, Seropédica, RJ, Brasil. E-mail: adivaldo@ufrrj.br. Autor para correspondência.
} 
role that $\boldsymbol{R}$. sanguineus plays in the transmission of Ehrlichia canis (PEREZ et al., 1996; UNVER et al., 2001) and Rickettsia spp. (DEMMA et al., 2005; WIKSWO et al., 2007; PIRANDA et al., 2008; CUNHA et al., 2009). In addition, research has studied its involvement, under laboratory conditions, in the epidemiology of canine visceral leishmaniasis (COUTINHO et al., 2005).

Concerning the ticks, artificial feeding methods afford the potential (i) to assess the arthropod's efficiency as a disease vector, (ii) to expose it to predefined pathogen concentrations, and (iii) to reduce the number of host animals required in laboratory experiments on pathogen transmission (HOKAMA et al., 1987). The definition of an experimental model to study the tick-pathogen relationship, in the absence of a host, may significantly add to the current knowledge about pathogen transmission pathways.

The method of artificial feeding does not promote full engorgement of the specimens and fails to perfectly replicate natural feeding conditions; on the other hand, it reduces the number of variables to be considered in the tick feeding process (JASINSKAS et al., 2000). In this scenario, the present study assesses the weight gain of partially engorged $\boldsymbol{R}$. sanguineus females that were artificially fed via capillary tubes and the influence of capillary tube feeding on the biological parameters of the non-parasitic stage of the species.

\section{MATERIALS AND METHODS}

Rhipicephalus sanguineus utilized in the experiment were collected from stray dogs, and subsequently, these ticks were maintained in the Laboratory of Parasitic Diseases, Department of Epidemiology and Public Health, Federal Rural University of the State of Rio de Janeiro.

To obtain partially engorged females, an experimental infestation of mixed-breed rabbits (Oryctolagus cuniculus) with 20 R. sanguineus couples per animal was conducted as described in NEITZ et al. (1971). During this experimental phase, all hosts were kept in individual cages and given water and commercial feed ad libitum daily. The protocol of Ethical Principles for Animal Research of the Brazilian College of Animal Experiments was observed throughout the experiment.

On the day 7 of infestation, the partially engorged females were recovered from hosts by manual twisting; the females were then washed, dried and weighed using an analytical scale. The artificial feeding process was conducted as follows. Forty female ticks were selected in terms of weight and integrity of mouthparts. The females were sorted into four groups, each with ten ticks of homogeneous weight. The females were fixed on Styrofoam trays, ventral side upwards, using double-face adhesive tape.

The capillary feeding of ticks in each treatment group occurred over four different feeding times: 2, 6, 12 and 24 hours. The blood utilized was aseptically collected from the radial vein of a healthy dog and was transferred to a tube containing citrate as an anti-clotting agent. The material was conserved under refrigeration $\left(4^{\circ} \mathrm{C}\right)$ and was heated to $37^{\circ} \mathrm{C}$ prior to capillary tube filling. The capillary tubes were placed onto the mouthparts of the ticks. The ticks were subsequently transferred to a biological oxygen demand (BOD) incubator at $27^{\circ} \mathrm{C}$ with relative humidity (R.H.) $85 \pm 5 \%$. The capillary tubes were replaced every 30 min to prevent the obstruction of blood flow. At the end of each feeding period, the females of each group were immediately washed, dried and weighed to assess blood intake. For the measurement of biological parameters, the females were fixed on Petri dishes and incubated, as described above, for oviposition.

During the investigation on the non-parasitic stage of $\boldsymbol{R}$. sanguineus females that were artificially fed via capillary tubes, the following parameters were measured: weight of females after capillary feeding (mg); pre-oviposition period (days); oviposition periods (days); oviposition weight (mg); Egg Production Index (EPI); Nutritional Efficiency Index (NEI) (BENNET, 1974); Estimated Reproduction (ER) (DRUMMOND et al., 1973); and percentage of larva eclosion (BELLATO \& DAEMON, 1997). For the analysis of weight gain of the artificially fed females, the means of the biological parameters were analyzed using the non-parametrical Dunn and Kruskal-Wallis tests with a 5\% significance level. In order to perform a linear regression, the significance of the following relationships was assessed: the weight gain of females and the periods of artificial feeding; and the weights of females and oviposition.

\section{RESULTS AND DISCUSSION}

The weight of the artificially fed groups increased as the time exposed to the capillary increased, and this relationship was highly significant $(\mathrm{P}<0.05)$ between the groups fed for 2 and 24 hours (Table 1). It was observed some of the specimens in each group lost weight over the respective feeding period.

Similar results were observed by ABEL (2004) in a study involving partially engorged Amblyomma cajennense females that were fed via capillary tubes. In that investigation, the females fed 
Table 1 - Average weight of the Rhipicephalus sanguineus females before and after artificial feeding through capillary tubes for four different feeding times: 2, 6, 12 and 24 hours. Mean \pm SE (range in parentheses).

\begin{tabular}{lccc}
\hline Feeding times & Before & After & Weight gain \\
\hline 2 hours $(\mathrm{n}=10)$ & $61.6 \pm 48.4(21.9-172.3)$ & $61.7 \pm 47.2(21.4-170.5)$ & $0.2 \pm 2.4^{\mathrm{a}}(-2.2-6.1)^{*}$ \\
6 hours $(\mathrm{n}=10)$ & $61.6 \pm 47.7(22.4-161.9)$ & $66.0 \pm 44.4(24.9-158.8)$ & $4.3 \pm 5.8^{\mathrm{ab}}(-3.1-15.5)^{*}$ \\
12 hours $(\mathrm{n}=10)$ & $61.7 \pm 48.3(22.7-169.5)$ & $69.1 \pm 44.4(32.1-168.3)$ & $7.4 \pm 5.8^{\mathrm{ab}}(-1.2-14.4)^{*}$ \\
24 hours $(\mathrm{n}=10)$ & $61.6 \pm 44.2(22.1-135.0)$ & $73.6 \pm 37.3(32.1-141.3)$ & $12.0 \pm 11.2^{\mathrm{b}}(-2.3-33.1)^{*}$ \\
\hline
\end{tabular}

*Values followed by different letters in the same column indicate significant differences $(\mathrm{P}>0.05)$.

for a period of 6 hours or more; as a result, the females ingested a high volume of blood. This was the first record of an expressive blood intake by ticks using the artificial feeding technique.

Although the use of an artificial feeding technique via capillary tubes has not been proven to provide full engorgement of $\boldsymbol{R}$. sanguineus females, results such as these should be taken into account in investigations that aim at the experimental infection of these species. According to BROADWATER et al. (2002), the capillary feeding technique is essential in studies that investigate the infection of immature ticks, since it is less invasive as compared to other infection methods, including percutaneous injection. In a review by BURGDORFER (1957), the author reported that the capillary feeding technique has been used to infect the ticks Hyalomma excavatum, H. dromedarii, Dermacentor pictus and $R$. sanguineus with Leptospira pomona.

BROADWATER et al. (2002) reported that the small amount of solution injected can be explained by the artificial character of the method and by the insertion of the tick's palps into the capillaries. Nevertheless, PURNELL \& JOYNER (1967) observed that, in experiments in which the palps were not inserted into the capillaries, the palps were able to move and insert into the tubes, as in the present study. Some researchers have criticized the experimental factors as responsible for the technique's failures, such as the concomitance of mechanical and chemical events that take place in the pre-feeding stage of ticks, the long fixation periods, and the parasite-host interaction (BROWN, 1989; FONSECA, 1990; ABEL, 2004).

The present study verified that the long capillary exposure periods can cause the blood to dry out at the capillary end. This blocked the blood flow through the tube and made it necessary to replace the capillaries every $30 \mathrm{~min}$ to provide constant feeding to the ticks. On the other hand, some studies have blamed capillary obstruction on the cement production by the ticks (PURNELL \& JOYNER, 1967).
The capillary tube feeding technique offers an advantageous trade-off, as there is no need for storing blood, which, if required, may lead to the production of toxins (OSBORNE \& MELLOR, 1986) and contamination by microorganisms. Therefore, the capillary feeding technique eliminates the need for preservants like antibiotics and antifungal agents, as well as other supplements (STONE et al., 1983).

Table 2 shows the results for the biological parameters of the artificially fed females. No statistically significant differences $(\mathrm{P}>0.05)$ were observed in the biological parameters between the females treated for the different capillary feeding times. This result suggests that capillary feeding for long periods does not impact the performance of $\boldsymbol{R}$. sanguineus females. SWEATMAN (1967) has reported that the volume of blood ingested is not the only factor that influences egg production efficiency. According to the authors, the amount of cuticle the female produces also plays a role in oviposition.

When the weight gain of $\boldsymbol{R}$. sanguineus females that were fed via capillary tubes for different periods was evaluated, it was observed that a longer feeding period was associated with a higher weight gain ( $\mathrm{r}=0.53$ ) (Figure 1). This result disagrees with those obtained by GREGSON (1957), who reported that ticks ingest blood offered via capillaries for only a limited period of time. Also, BURGDORFER (1956) observed that the feeding period is limited to between four and six hours unless fresh blood suspensions are offered.

A correlation $(r=0.97)$ between the weight of the females after capillary feeding and the total weight of the eggs laid was observed (Figure 2). This result demonstrates that a higher weight gain of the females during the capillary feeding period is associated with a heavier total weight of the eggs laid.

Artificial feeding via capillary tubes provides an efficient and easy method for the artificial intake of blood by $\boldsymbol{R}$. sanguineus. Furthermore, it was noted that the ticks fed in vitro were able to establish a new 
Table 2 - Biological parameters of the non-parasitic stage of Rhipicephalus sanguineus females fed via capillary tubes for different periods: 2, 6, 12 and 24 hours. Mean \pm SE (range in parentheses).

\begin{tabular}{|c|c|c|c|c|c|}
\hline \multirow[b]{2}{*}{ Biological parameters } & \multicolumn{4}{|c|}{------------------------Period of feed via capillaries tubes----------------------- } & \multirow[b]{2}{*}{ Reference* } \\
\hline & $\begin{array}{l}2 \text { hours } \\
(n=10)\end{array}$ & $\begin{array}{l}6 \text { hours } \\
(n=9)\end{array}$ & $\begin{array}{c}12 \text { hours } \\
\quad(n=8)\end{array}$ & $\begin{array}{l}24 \text { hours } \\
(n=10)\end{array}$ & \\
\hline Weight of females (mg) & $\begin{array}{l}61.7 \pm 47.2 \\
(21.4-170.5)\end{array}$ & $\begin{array}{l}66.0 \pm 44.4 \\
(24.9-158.8)\end{array}$ & $\begin{array}{l}69.1 \pm 44.4 \\
(32.1-168.3)\end{array}$ & $\begin{array}{l}73.6 \pm 37.3 \\
(32.1-141.3)\end{array}$ & $\begin{array}{l}178.8 \pm 6.1 \\
(128.5-236.0)\end{array}$ \\
\hline Pre-oviposition period (days) & $\begin{array}{l}4.9 \pm 1.5^{\mathrm{a}} \\
(3.0-8.0)\end{array}$ & $\begin{array}{l}3.7 \pm 1.6^{\mathrm{a}} \\
(0.0-5.0)\end{array}$ & $\begin{array}{l}3.2 \pm 1.9^{\mathrm{a}} \\
(0.0-6.0)\end{array}$ & $\begin{array}{l}4.9 \pm 1.0^{\mathrm{a}} \\
(4.0-7.0)\end{array}$ & $\begin{array}{l}3.19 \pm 0.11 \\
(2.0-4.0)\end{array}$ \\
\hline Oviposition periods (days) & $\begin{array}{l}6.3 \pm 2.7^{\mathrm{a}} \\
(3.0-12.0)\end{array}$ & $\begin{array}{l}6.2 \pm 3.4^{\mathrm{a}} \\
(0.0-12.0)\end{array}$ & $\begin{array}{l}6.1 \pm 3.7^{\mathrm{a}} \\
(0.0-11.0)\end{array}$ & $\begin{array}{l}6.9 \pm 2.9^{\mathrm{a}} \\
(1.0-11.0)\end{array}$ & $\begin{array}{l}13.71 \pm 0.49 \\
(9.0-18.0)\end{array}$ \\
\hline Oviposition weight (mg) & $\begin{array}{l}31.5 \pm 33.1^{\mathrm{a}} \\
(3.7-107.8)\end{array}$ & $\begin{array}{l}38.4 \pm 33.9^{\mathrm{a}} \\
(0.0-106.3)\end{array}$ & $\begin{array}{l}37.5 \pm 35.7^{\mathrm{a}} \\
(0.0-108.5)\end{array}$ & $\begin{array}{l}41.6 \pm 29.2^{\mathrm{a}} \\
(1.1-94.3)\end{array}$ & $\begin{array}{l}114.27 \pm 4.22 \\
(67.4-156.0)\end{array}$ \\
\hline EPI & $\begin{array}{l}43.7 \pm 18.8^{a} \\
(10.7-67.8)\end{array}$ & $\begin{array}{l}50.3 \pm 19.9^{a} \\
(0.0-68.2)\end{array}$ & $\begin{array}{l}46.6 \pm 25.6^{a} \\
(0.0-70.8)\end{array}$ & $\begin{array}{l}51.1 \pm 18.3^{\mathrm{a}} \\
(3.2-66.7)\end{array}$ & $\begin{array}{l}63.89 \pm 1.0 \\
(50.9-67.6)\end{array}$ \\
\hline NEI & $\begin{array}{l}76.0 \pm 12.2^{a} \\
(50.0-90.5)\end{array}$ & $\begin{array}{l}78.0 \pm 28.3^{\mathrm{a}} \\
(0.0-97.3)\end{array}$ & $\begin{array}{l}68.5 \pm 36.5 \\
(0.0-95.3)\end{array}$ & $\begin{array}{l}82.3 \pm 17.8^{a} \\
(32.4-93.6)\end{array}$ & $\begin{array}{l}79.77 \pm 0.87 \\
(66.10-83.8)\end{array}$ \\
\hline ER & $\begin{array}{l}32.8 \pm 20.2^{\mathrm{a}} \\
(5.3-61.0)\end{array}$ & $\begin{array}{l}40.9 \pm 18.2^{\mathrm{a}} \\
(0.0-61.4)\end{array}$ & $\begin{array}{l}43.6 \pm 23.9^{a} \\
(0-65.9)\end{array}$ & $\begin{array}{l}37.2 \pm 18.0^{a} \\
(0.6-58.4)\end{array}$ & --- \\
\hline $\begin{array}{l}\text { Percentage of larva eclosion } \\
(\%)\end{array}$ & $\begin{array}{l}74.0 \pm 28.4^{\mathrm{a}} \\
(10-100)\end{array}$ & $\begin{array}{l}73.0 \pm 29.5^{\mathrm{a}} \\
(0-90)\end{array}$ & $\begin{array}{l}75.0 \pm 39.8^{\mathrm{a}} \\
(0-100)\end{array}$ & $\begin{array}{l}68.0 \pm 27.0^{\mathrm{a}} \\
(20-100)\end{array}$ & $\begin{array}{l}84.43 \pm 5.57 \\
(7-99)\end{array}$ \\
\hline
\end{tabular}

EPI= Egg Production Index; NEI= Nutritional Efficiency Index; ER= Estimated reproduction

No statistically significant differences $(\mathrm{P}>0.05)$ were observed in the biological parameters between the females treated for the different capillary feeding times.

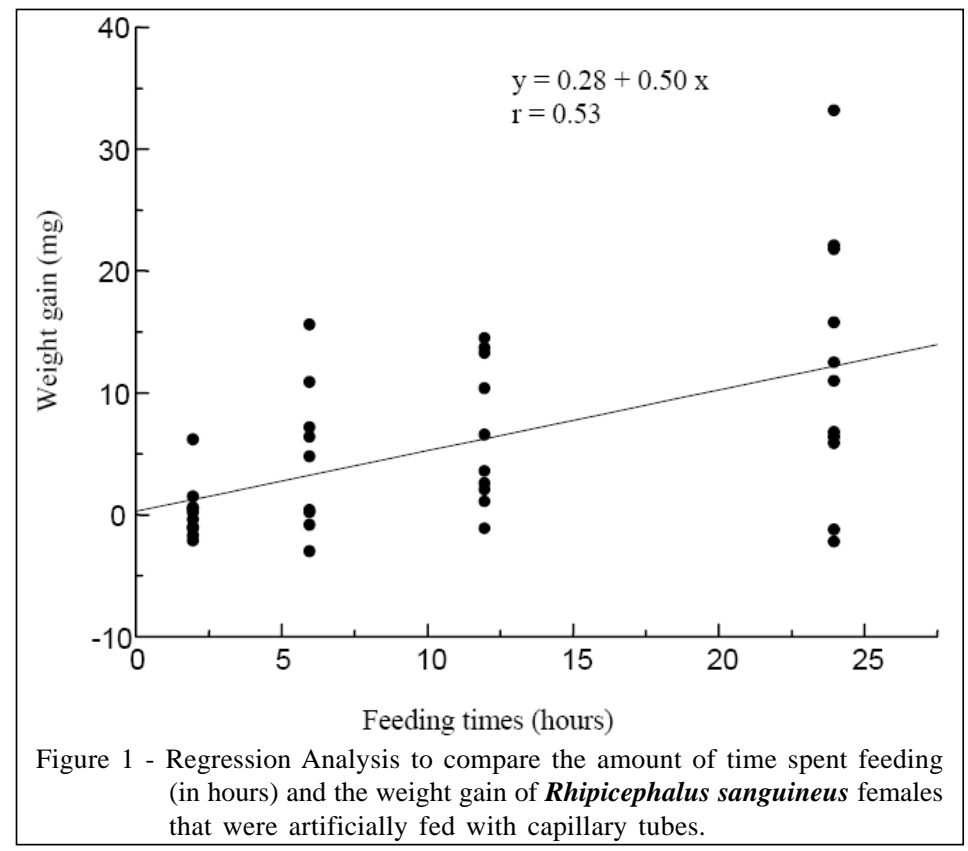

Ciência Rural, v.40, n.4, abr, 2010. 


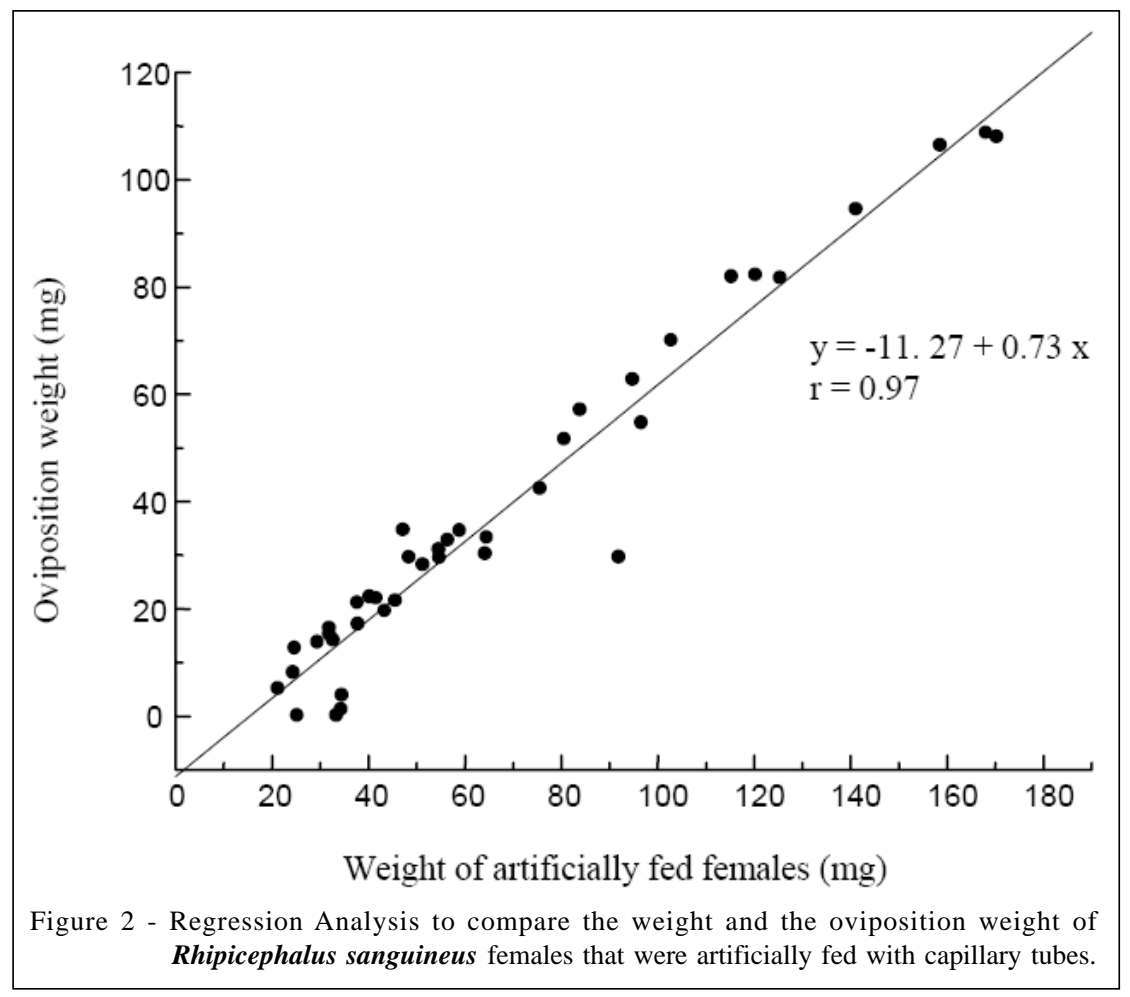

generation. The experimental method shows great promise in studies aimed at investigating biological disease agents.

\section{ACKNOWLEDGMENTS}

The research was supported by the Fundação Carlos Chagas Filho de Amparo à Pesquisa do Estado do Rio de Janeiro (FAPERJ) and the Conselho Nacional de Desenvolvimento Científico e Tecnológico (CNPq).

\section{REFERENCES}

ABEL, I. Alimentação artificial de fêmeas de Amblyomma cajennense (Fabricius, 1787) (Acari: Ixodidae) através de tubos capilares. 2004. 56f. Tese (Doutorado em Ciências Veterinárias) - Curso de Pós-graduação em Ciências Veterinárias, Universidade Federal Rural do Rio de Janeiro, Seropédica, RJ.

BELLATO, V.; DAEMON, E. Efeitos de três temperaturas sobre a fase não parasitária de Rhipicephalus sanguineus (Latreille, 1806) (Acari: Ixodidae). Revista Brasileira de Parasitologia Veterinária, v.6, n.1, p.21-27, 1997. Available from: <http://www.cbpv.com.br /documentos/611997/ c6121_27.pdf>. Accessed: dez. 20, 2008.

BENNET, G.F. Oviposition of Boophilus microplus (Canestrini) (ACARIDIDA: IXODIDAE): (I. Influence of tick size on egg production). Acarology, v.16, n.1, p.52-61, 1974. Available from: <http://lrs.afpmb.org/AAFPPEYBUNZ4SMMQY8ZECQRB/arc / al_06_tit_fetch/1/82512>. Accessed: jan. 03, 2009.
BROADWATER, A.H. et al. Glass capillary tube feeding: a method for infecting nymphal Ixodes scapularis (Acari: Ixodidae) with the Lyme disease spirochete Borrelia burgdorferi. Journal of Medical Entomology, v.39, n.2, p.285-292, 2002. Available from: <http://www. bioone.org/doi/pdf/10.1603/00222585-39.2.285>. Accessed: jan. 05, 2009. doi: 10.1603/00222585-39.2.285.

BROWN, S.J. Pathological consequences of feeding by haematophagous arthropods: comparison of feeding strategies. Miscellaneous Publications of the Entomological Society of America, v.71, n.1, p.4-14, 1989.

BURGDORFER, $\mathrm{W}$. The possible role of ticks as vectors of leptospirae I. Transmission of Leptospira pomona by the argasid tick, Ornithodoros turicata, and the persistance of this organism in its tissues. Experimental Parasitology, v.5, n.6, p.571579, 1956.

BURGDORFER, W. Artificial feeding of ixodid ticks for studies on the transmission of disease agents. Journal of Infectious Diseases, v.100, n.3, p.212-214, 1957.

COUTINHO, M.T.Z. et al. Participation of Rhipicephalus sanguineus (Acari: Ixodidae) in the epidemiology of canine visceral leishmaniasis. Veterinary Parasitology, v.128, n.1-2, p.149-155, 2005. Available from : < h t t p : / / w w w. sciencedirect.com / science?_ob=MImg\&_imagekey=B6TD7-4F2VS7T-5-

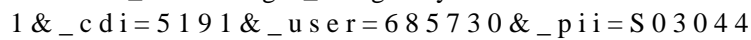
01704005461\&_orig=browse\&_coverDate $=03 \% 2 F 10 \% 2 F 2005 \& \_s k=9$ 98719998 \& vi e w = c \& w c h p = d G L b V l W zSkWA\&md5=20e5ac5462e6ee3cb4145ae99b2c3c75\&ie=/sdarticle.pdf $>$. Accessed: jan. 05, 2009.

Ciência Rural, v.40, n.4, abr, 2010. 
CUNHA, N.C. et al. First identification of natural infection of Rickettsia rickettsii in the Rhipicephalus sanguineus tick, in the State of Rio de Janeiro. Pesquisa Veterinária Brasileira, v.29, n.2, p.105-108, 2009. Available from: <http:/ /www.scielo.br/scielo.php?scrip t=sci_arttext\&pid=S0100736X2009000200003\&lng=pt\&nrm=iso $>$. Accessed: fev. 15, 2009. doi: 10.1590/S0100-736X2009000200003.

DEMMA, L.J. et al. Rocky Moutain spotted fever from an unexpected tick vector in Arizona. New England Journal of Medicine, v.353, n.6, p.587-594, 2005. Available from: <http:/ /ovidsp.tx.ovid.com/sp-2.3/ovidweb.cgi?\&S=MFCHFPNODBD DIJAENCELEHJNPMOAA00\&Link+Set=S.sh.15.16.19.40\%7c9\%7csl_10>. Accessed: nov. 15, 2008.

DRUMMOND, R.O. et al. Boophilus annulatus and Boophilus microplus: laboratory test of insecticides. Journal of Economic Entomology, v.66, n.1, p.130-133, 1973.

FONSECA, A.H. Funções da saliva dos ixodídeos. A Hora Veterinária, v.10, n.56, p.43-46, 1990.

GREGSON, J.D. Experiments on the oral secretion of the Rocky mountain wood tick Dermacentor andersoni (Stiles). Canadian Entomologist, v.89, n.1, p.1-5, 1957.

HOKAMA, Y. et al. Maintenance of adult and nymphal Ornithodoros coriaceus (Acari:Argasidae) by artificial feeding through a parafilm membrane. Journal of Medical Entomology, v.24, n.3, p.319-323, 1987. Available from: <http://lrs.afpmb.org/KC9EZYQYTR08MCGRA4MTPBZP/ arc/al_06_tit_fetch/1/132530>. Accessed: out. 12, 2008.

JASINSKAS, A. et al. Amblyomma americanum: specific uptake of immunoglobulins into tick hemoplymph during feeding. Experimental Parasitology, v.96, n.4, p.213-221, 2000. Available from: <http:// www.sciencedirect.com/science?_ob=MImg\&_imagekey=B6WFH45FBY7B-3- 1 \&_cdi $=6795 \&$ _user $=685730 \&$ \& $14489400945673 \&$ \&_orig = browse \&_coverDate $=12 \% 2 F 31 \% 2 F 2000 \& \_s k=999039995 \& v i e w=c \& w c h p=d G L b V t b-$ zSkWz\&md5=a15d388507aa862ff251c8b3254442c2\&ie =/ sdarticle.pdf>. Accessed: out. 12, 2008.

NEITZ, W.O. et al. Laboratory investigations of the life-cycle of karoo paralysis tick (Ixodes rubicundus Neumann, 1904). Onderstepoort Journal of Veterinary Research, v.38, n.3, p.215-224, 1971.

OSBORNE, R.W.; MELLOR, P.S. Development and mortality of Ornithodoros moubata after feeding through an artificial membrane. Tropical Animal Health and Production, v.18, n.1, p.41-47, 1986. Available from: <http://lrs.afpmb.org/ HFM5VY5YAU6G7MT5 HQTHHR0V/arc/al_06_tit_fetch/2/ 136353>. Accessed:out.20,2008.doi:0.1007/BF02359657.

PEREZ, M. et al. Ehrlichia canis-like agent isolated from a man in Venezuela: antigenic and genetic characterization.
Journal of Clinical Microbiology, v.34, n.9, p.2133-2139, 1996. Available from: <http://jcm.asm.org/cgi/reprint/34/9/ 2133 ? $\mathrm{maxtoshow}=\& \mathrm{H} \mathrm{I} \mathrm{T} \mathrm{S}=10 \& \mathrm{hit} \mathrm{s}=10$ $\&$ RESULTFORMAT $=\&$ fulltext $=$ Ehrlichia + canis li ke + a ge n t + is olated + from $+a+m a n+i n+$ Venezuela\%3 $\mathrm{A}+$ antigenic + and + genetic + characte rization\&searchid=1\&FIRSTINDEX=0\&resourcetype $=$ HWCIT $>$. Accessed: out. 20, 2008.

PIRANDA, E.M. et al. Experimental infection of dogs with a Brazilian strain of Rickettsia rickettsii: clinical and laboratory findings. Memórias do Instituto Oswaldo Cruz, v.103, n.7, p.696-701, 2008. Available from: <http://www.scielo.br/scielo.php?script=sci_arttext\&pi d=S007402762008000700012\&lng=en\&nrm=iso>. Accessed: dez. 12, 2008. doi: 10.1590/S0074-02762008000700012.

PURNELL, R.E.; JOYNER, L.P. Artificial feeding technique for Rhipicephalus appendiculatus and the transmission of Theileria parva from the salivary secretion. Nature, v.216, n.5114, p.484-485, 1967.

STONE, B.F. et al. Artificial feeding of the Australian paralysis tick, Ixodes holocyclus and collection of paralysing toxin. International Journal for Parasitology, v.13, n.5, p.447454, 1983. Available from: <http://lrs.afpmb.org/ 3CZP50ZUY9BZMVDGP829SSXX/arc/al_06_tit_fetch/3/ 119552>. Accessed: dez. 12, 2008 . doi: 10.1016/S00207519(83)80007-1

SWEATMAN, G.K. Physical and biological factors affectting the longevity and oviposition of engorged Rhipicephalus sanguineus female ticks. Journal of Parasitology, v.53, n.2, p.432-445, 1967. Available from: <http://lrs.afpmb.org/ KC9EZYQYTR08MCGRA4MTPBZ P/arc/al_06_tit_fetch/1/ 35274>. Accessed: dez. 12, 2008.

UNVER, A. et al. Molecular and antigenic comparison of Ehrlichia canis isolates from dogs, ticks, and a human in Venezuela. Journal of Clinical Microbiology, v.39, n.8, p.2788-2793, 2001. Available from: <http://jcm.asm.org/cgi/ reprint $/ 39 / 8 / 2788$ ? $\mathrm{maxt}$ oshow $=\&$ H I T S $=10 \&$ hi $\mathrm{ts}=10 \&$ RESULTFORMAT $=\&$ fulltext $=$ Molecular+an $\mathrm{d}+$ antigenic + comparison + of + Ehrlichia + canis + isolates + from + do gs\%2C+ticks\%2C+and+a+human+in+Venezuela\&se archid=1\&FIRSTINDEX=0 \& resourcetype $=$ HWCIT $>$. Accessed: jan. 08, 2009

WIKSWO, M.E. et al. Detection of Rickettsia rickettsii and Bartonella henselae in Rhipicephalus sanguineus ticks from California. Journal of Medical Entomology, v.44, n.1, p.158-162, 2007. Available from: < http://www.bioone.org/doi/full/10.1603/00222585\%282007\%2944\%5B158\%3ADORRAB\%5D2.0.CO\%3B2>. Accessed: out. 14, 2008 . doi: 10.1603/00222585(2007)44[158:DORRAB]2.0.CO;2. 